\title{
Wiaczesław Wsiewołodowicz Iwanow (1929-2017)
}

Bogusław Żyłko

TEKSTY DRUGIE 2021, NR 3, S. 352-359

DOI: 10.18318/td.2021.3.23 | ORCID: 0000-0003-4605-0719

$\mathbf{U}$ rodził się 21 sierpnia 1929 roku w Moskwie, zmarł 7 października 2017 roku w Los Angeles. Przyszedł na świat w rodzinie znanego i uznanego pisarza, Wsiewołoda Iwanowa, należącego do nowej elity, formującej się po ustaniu walk frakcyjnych i przejęciu pełni władzy przez Stalina i jego ekipę. Wódz aktywnie uczestniczył w tym procesie, podejmując wszystkie najważniejsze decyzje, w tym także dotyczące warunków życia i pracy. Za namową Maksyma Gorkiego kazał wybudować na początku lat 20. w lesie w podmoskiewskim Pieriediełkinie osadę willową, składającą się z kilkudziesięciu domów w stylu rosyjskich daczy, a pod koniec tej dekady wzniesśc w historycznym centrum Moskwy, w Zaułku Eawruszyńskim, ogromny wielorodzinny dom mieszkalny, znany potem jako „Dom Pisarza”. Zapewnił w ten sposób „inżynierom dusz" dobre warunki do pracy i wypoczynku, poddając ich jednocześnie czujnej kontroli, sprawowanej przez niezwykle rozbudowany w porewolucyjnej Rosji aparat bezpieczeństwa. Wsiewołod Iwanow, choć nie należał do pisarzy reżymowych (wywodził się z ugrupowania Bracia

\author{
Bogusław \\ Żyłko - profesor \\ emerytowany \\ Uniwersytetu \\ Gdańskiego, profesor \\ zwyczajny Akademii \\ Humanistyczno- \\ -Ekonomicznej \\ w Łodzi. Zajmuje się \\ semiotyką kultury \\ (autor książek \\ o szkole tartusko- \\ -moskiewskiej), \\ rosyjskimi \\ doktrynami \\ estetycznymi \\ (zwłaszcza \\ literaturoznawczymi) \\ XX wieku, twórczością \\ naukowo-filozoficzną \\ M. Bachtina, \\ historią idei. Autor \\ wielu przekładów \\ z humanistyki \\ rosyjskiej tego okresu \\ (m.in. opublikował \\ we własnym \\ tłumaczeniu \\ i opracowaniu \\ kilkanaście tomów \\ prac semiotyków \\ z grupy Tartu- \\ Moskwa).
}


Serafiońscy, programowo odżegnującego się od bieżącej polityki i kładącego raczej nacisk na sprawy warsztatowe sztuki słowa), znalazł się na liście szczęśliwców z uwagi na swój niewątpliwy talent literacki, podobnie jak wielu innych wybitnych twórców.

Dzieciństwo i młodość Wiaczesława Iwanowa upłynęły zatem w szczególnych miejscach i w kontaktach z niepospolitymi ludźmi. Z powodu wrodzonej choroby kości nie mógł uczęszczać do normalnej szkoły i musiał „przerabiać” jej program w domu. Nieobecność nauczycieli z naddatkiem rekompensowali znakomici sąsiedzi, z których jeden - Korniej Czukowski - uczył malca angielskiego, a w arkana fizyki (to już w późniejszym wieku) wprowadzał go Piotr Kapica. Wielką rolę w tym kształceniu, które szybko przemieniło się w samokształcenie, odegrała ogromna biblioteka ojca, gromadząca dzieła z wielu różnych dziedzin wiedzy, z której skarbów Wiaczesław dość szybko nauczył się samodzielnie korzystać. (Z biblioteki w moskiewskim mieszkaniu korzystał Wiktor Szkłowski, mieszkający na tej samej klatce schodowej. Młodziutki Iwanow zapamiętał szybkość, z jaką Szkłowski pochłaniał książki: pożyczoną jednego dnia książkę przynosił nazajutrz i brał następną). Tu się kryje się tajemnica jego zadziwiającej erudycji i sekret jego pisarstwa naukowego (zwłaszcza prac z historii nauki), które przypomina nizanie na przewodnią nić tematyczną skojarzeń myślowych, biorących się z tych niezwykle rozległych lektur. To misterne splatanie myśli pochodzących z bardzo różnych i na pozór odległych źródeł bez popadania przy tym w eklektyzm stanowi najwyraźniejszą cechę poetyki jego prac. Przy okazji warto by było odnieść się do jednej plotki biograficznej, zgodnie z którą ojcem biologicznym przyszłego uczonego miał być Izaak Babel (również mieszkaniec Pieriediełkina). Historia wyglądała jednak inaczej: matka miała wcześniej romans z Bablem, jego owocem był chłopiec, Misza, który potem stał się członkiem rodziny Iwanowów. O tych skomplikowanych perypetiach rodzinnych późniejszy uczony dużo pisał w rozmaitych autobiograficznych wypowiedziach w ostatnim okresie życia.

Pieriediełkino stanowi niewątpliwie centrum życiowej topografii Wiaczesława Iwanowa. To właśnie miejsce w połączeniu z zamieszkującymi je ludźmi chyba najbardziej określiło jego osobowość i fundamenty światopoglądu. A w tym minichronotopie najważniejsze było sąsiedztwo z daczą Borysa Pasternaka. Latem 2013 roku uczestnicy kongresu zorganizowanego w Moskwie dla uczczenia stulecia rosyjskiej szkoły formalnej mogli ją zwiedzić w towarzystwie Iwanowa, odgrywającego rolę kompetentnego przewodnika. Znał każde z pomieszczeń dużego piętrowego domu, przypominał ich 
wystrój i funkcje, jakie pełniły za życia sławnego gospodarza. Opowiadał przy okazji o bliskiej znajomości, jaka istniała (pomimo dużej różnicy wiekowej) pomiędzy nimi. Iwanow informował poetę o nowych odkryciach w naukach matematyczno-przyrodniczych, którymi ten ostatni miał się bardzo interesować. W latach chruszczowowskiej odwilży ożywiła się wymiana informacji naukowej z Zachodem, z wielu nauk (cybernetyka, genetyka, teoria informacji) zdjęto piętno "nauk burżuazyjnych" i Iwanow ze swoją znajomością języków zachodnich (w 1951 roku ukończył filologię romańsko-germańską na Uniwersytecie Moskiewskim) oraz dostępem do bibliotek naukowych z zagranicznymi nowościami mógł być bardzo dobrym informatorem.

Przyjaźń z Pasternakiem, bo tak ich relacje można nazwać, zaważyła w pewien sposób na przebiegu kariery naukowej Wiaczesława Iwanowa. Po studiach rozpoczął on pracę na swojej Alma Mater i szybko, bo już w 1955 roku obronił pracę doktorską, którą chciano uznać od razu za rozprawę habilitacyjną (w nomenklaturze radzieckiej - dysertacja kandydacka jako doktorska). Ale doktorem habilitowanym nie został, bo papiery „zawieruszyły się” w wyższej komisji kwalifikacyjnej, zatwierdzającej przyznane stopnie naukowe. (Habilitację uzyskał dopiero w 1978 roku i nie w Moskwie, ale w Wilnie). Dobrze zapowiadająca się kariera uniwersytecka zostaje przerwana w 1958 roku, kiedy Iwanow staje w obronie swojego sąsiada w Pieriediełkinie, na którego zewsząd posypały się gromy i obelgi po opublikowaniu na Zachodzie powieści Doktor Żywago. Nagonkę tę pisarz przypłacił życiem (odszedł przedwcześnie w 1960 roku), Iwanow natomiast musiał kontynuować pracę naukową w placówkach badawczych Akademii Nauk, z zasady niezajmujących się dydaktyką. Najdłużej był związany z Instytutem Słowianoznawstwa i Bałkanistyki, kierując w nim Sekcją Lingwistyki Strukturalnej (sama jej nazwa znamionowała powiew nowych idei naukowych, których Iwanow był generatorem lub przynajmniej przekaźnikiem). Z Władimirem Toporowem tworzył duet badawczy, którego największym osiągnięciem była rekonstrukcja tzw. "mitu podstawowego", przeprowadzona na ogromnym materiale historyczno-porównawczym. Do zajęć uniwersyteckich mógł powrócić dopiero pod koniec pieriestrojki, kiedy to Uniwersytet Moskiewski anulował swoją decyzję sprzed trzydziestu lat i umożliwił mu utworzenie Instytutu Kultury Światowej. Równolegle na nowo powstałym Państwowym Rosyjskim Uniwersytecie Humanistycznym kierował Rosyjską Szkołą Antropologiczną. Korzystał także z zaproszeń uniwersytetów amerykańskich. Zmarł w Los Angeles jako profesor slawistyki Uniwersytetu Kalifornijskiego. Spoczął obok rodziców na cmentarzu Nowodziewiczym w Moskwie. 
Już powyższa lista miejsc pracy (a nie jest to pełen wykaz) wskazuje na zakres przedmiotowy zainteresowań naukowych Iwanowa. Od indoeuropeistyki (ona stanowi już cały osobny świat) do antropologii kulturowej - tak w skrócie wyglądało poszerzanie się jego pola obserwacyjnego. Zaczynał od pierwszej dziedziny i prace "na stopnie” dotyczyły samego jej rdzenia („korzenie indoeuropejskie w hetyckim języku klinowym”, ,odbicie indoeuropejskich form czasownikowych w językach bałtosłowiańskich"), a ich zwieńczeniem była wielka dwutomowa monografia z 1984 roku (napisana wespół z gruzińskim indoeuropeistą Tomasem W. Gamkrelidze) Język indoeuropejski i indoeuropejczycy. Rekonstrukcja i analiza historyczno-literacka prajęzyka i protokultury. Od samego początku ten główny nurt badań obrastał w liczne inne działania na terenie innych dyscyplin, z których najważniejsze to: nauka o literaturze (komparatystyka), mitologia i folklorystyka, filmoznawstwo (prace o S. Eisensteinie), neurofizjologia (rozprawy o asymetrii półkul mózgowych), historia nauki (dzieje współczesnej semiotyki). Nic dziwnego, że w końcu musiał dojść do projektu antropologii kulturowej jako ogólnej nauki o człowieku, w której wszystkie wymienione (i niewymienione) specjalności znalazłyby swoje ostateczne uzasadnienie.

Badaczowi kultury Wiaczesław Iwanow oczywiście będzie się kojarzyć z grupą uczonych, która do historii XX-wiecznej humanistyki weszła pod nazwą tartusko-moskiewskiej (albo - moskiewsko-tartuskiej) szkoły semiotyki kultury. I jej początek także wiąże się z podmoskiewskim Pieriediełkinem (obecnie to już część Moskwy, której przed zachłannymi deweloperami bronią miłośnicy historii). Tutaj na początku lat 6o. Iwanowa odwiedził Jurij Łotman, by zaproponować moskwianom współpracę. Iwanow, jak napisał potem w bardzo interesujących wspomnieniach, od razu polubił tego „wesołego wąsala" i wkrótce doprowadziło to do zorganizowania w ośrodku sportowym Uniwersytetu Tartuskiego pierwszej letniej szkoły semiotycznej, co stało się aktem założycielskim dla całego, znaczącego nawet w skali światowej ruchu naukowego. Dla Iwanowa jako językoznawcy akces do semiotyki był czymś naturalnym i dojrzenie w badanych przedmiotach działania swoistych systemów znakowych pozwoliło mu integrować rezultaty badań w jednolitym języku.

Ale semiotyka to nie tylko kwestia metajęzyka. W semiotyce Iwanow widział również metanaukę, możliwość urzeczywistnienia postulowanej nieraz zasady jedności wiedzy naukowej i społeczności uczonych, którzy - choć mają do czynienia $\mathrm{z}$ różnymi dziedzinami ( $\mathrm{w}$ fenomenologicznym rozumieniu tego słowa) - powinni jednak umieć znaleźć wspólny język. Być może dawały 
tu o sobie znać bliskie kontakty z fizykami (nie tylko Kapica, ale także Lew Landau, Andriej Sacharow i inni. byli w różnych okresach życia jego rozmówcami), dla których rozpatrywanie poznawanych rzeczy w ekstremalnie szerokiej, kosmogonicznej skali nie było czymś nadzwyczajnym. Humanistyka również miała zostać częścią tej meganauki, czyli po ostrych podziałach, spowodowanych przez tzw. przewrót antypozytywistyczny, miałby nastąpić (na wyższym szczeblu spirali rozwojowej) powrót do nowej jedni. Iwanow pisał kiedyś, że XXI wiek będzie wiekiem humanistyki, pod warunkiem że nie będzie odwracać się od najnowszych zdobyczy tzw. nauk ścisłych. Ciekawe byłoby poddanie tego proroctwa weryfikacji. Może warto by zapytać, czy obserwowane w dzisiejszych naukach humanistycznych dominujące tendencje tę przepowiednię potwierdzają.

Szkic, przedstawiający projekt ogólnego Symbolarium, jest jedną z ostatnich opublikowanych za życia prac Iwanowa. Oddaje on dobrze nie tylko styl myślenia samego autora, ale pod pewnymi względami jest charakterystyczny w ogóle dla mentalności rosyjskiej w sferze poszukiwań naukowych. Przede wszystkim wszechogarniający jest charakter tego projektu, który ma objąć całe doświadczenie historycznej ludzkości, utrwalone w najróżnorodniejszych symbolach. Iwanow nawiązuje do swojego sławnego poprzednika z pierwszej połowy ubiegłego wieku ojca Pawła Florenskiego, polihistora, którego zainteresowania rozciągały się od filozofii i teologii po zagadnienia wiecznej zmarzliny i przemysłowego wykorzystania morskich wodorostów. W rosyjskiej historii intelektualnej można wskazać niemało przykładów takich kosmicznych pod względem rozmachu i ambicji projektów. Ich wspólną cechą jest dążenie do absolutnej pełni, choć punktem wyjścia jest świadomość ograniczonych możliwości konkretnych podmiotów poznających. Nieprzypadkowo też wszechjedność wszystkiego, co istnieje, należy do głównych kategorii filozofii rosyjskiej. Wiaczesław Iwanow świetnie wpisuje się w tę tradycję, znakomicie się w niej orientując. Z jednej strony z łatwością przekracza, czasem arbitralnie wyznaczane, granice tradycyjnych dyscyplin naukowych, a z drugiej - podążając śladami swoich poprzedników, w tym Pawła Florenskiego - poszukuje momentów jednoczących, odnajdując je w symbolach. Florenski w swoim szeroko zakrojonym, ale jedynie zaczętym projekcie „symbolologii ogólnej” skupia się głównie na wizualnych „znakach ideograficznych" (za ich przykłady uważa znaki towarowe, heraldyczne, numizmatyczne, sfragistyczne, znaki używane w naukach średniowiecznych - alchemii, astrologii, filozofii przyrody) i proponuje podporządkować je „formalnej zasadzie mnożenia elementów geometrycznych" jako ich uniwersalnej 
matrycy generatywnej. Iwanow chce, aby ten przyszły tezaurus objął wszelkie symbole wizualne, werbalne, multimedialne - od reklamy i popkultury po sztukę wysoką i współczesną naukę. Dlatego też w swoich badaniach duże znaczenie przywiązuje do semiotyki, także jako wspomnianej metanauki. W odniesieniu na przykład do nauki tekst nabiera "naukowości" w fazie zapisu go w przyjętym przez wspólnotę naukową systemie znaków. W naukach formalnych (matematyka, logika) jest to oczywiste. Ale i w innych naukach matematyczno-przyrodniczych rola zapisu (notacji) jest sprawą zasadniczą. Mniej to jest oczywiste w humanistyce, choć i tutaj zapisywanie, tworzenie ciągu wyrażeń werbalnych wymaga włączenia operacji logicznych, bez których wywód nie będzie spełniał swoich warunków naukowości.

Semiotycy z Tartu i Moskwy zajęli się w latach 80. symbolem jako znakiem specyficznym i jego rolą w kulturze, poświęcając mu osobny zeszyt „Prac o systemach znakowych”. Jurij Łotman w symbolu widział reprezentanta - wyrażając się po Bachtinowsku - „wielkiego czasu kultury”, określał go mianem „kondensatora pamięci”, zdolnego do pomnażania sensów przy przechodzeniu przez kolejne epoki historyczne. Podczas gdy dla Łotmana kultura jest „informacją przekazywaną niedziedzicznie”, czyli taką, której należy się uczyć, Iwanow wykraczał poza granice kultury, jaką znamy i szukał zapowiedzi kompleksów znakowych w czasach prehistorycznych (rewolucja neolityczna) i wyposażeniu genetycznym człowieka.

Nauka nie była jedyną dziedziną, jaką uprawiał Wiaczesław Iwanow. Próbował też swoich sił na niwie literackiej jako tłumacz i poeta. Przekładał wiersze z 18 języków (w tym utwory Juliana Tuwima). Wiersze zaczął pisać w młodości, a jego słuchaczem i sędzią był Borys Pasternak, który z aprobatą miał odnieść się do jego prób poetyckich. Własnym wierszom nadawał raczej klasyczną formę (pisał między innymi sonety). Jeden utwór poświęcił osobie księdza Jerzego Popiełuszki, którego uprowadzenie i zabójstwo w październiku 1984 roku odbiło się głośnym echem także zagranicą. Nosi tytuł Pamięci kapłana Popiełuszki zabitego przez agentów polskiej bezpieki i zawiera sceny z pogrzebu duchownego. Nie ma w tym nic zaskakującego, ponieważ Iwanow, podobnie jak większość ludzi z jego kręgu, bardzo życzliwie odnosił się do Polski i jej kultury. Od lat 6o. często bywał w naszym kraju (brał udział w słynnych konferencjach z poetyki, organizowanych przez Instytut Badań Literackich PAN) i znał tu wielu ludzi. Obserwując audytorium i jego skład, zauważył, iż w Polsce (w odróżnieniu od Rosji) pomimo strat wojennych i powojennych represji nie nastąpiło całkowite zerwanie transmisji pokoleniowej, nie było luki pokoleniowej i ciągłość generacji została w dużej mierze 
zachowana. Dojrzewając w środowisku elitarnym, znajdującym się blisko władzy w jej najgorszym totalitarnym wydaniu, miał możliwość przyjrzenia się jej działaniom, tragicznie odbijającym się na losach ludzi z otoczenia jego rodziny. Jako osoba z niezależnym umysłem nie miał złudzeń co do prawdziwego charakteru tej władzy. Być może dlatego u schyłku Gorbaczowowskiej pieriestrojki nie chciał być już tylko świadkiem i postanowił czynnie włączyć się do polityki zostając z ramienia Akademii Nauk delegatem na Zjazd Deputowanych Ludowych, mający zdecydować o losach ZSRR. Tutaj dołączyłby do takich uczonych jak Andriej Sacharow lub Dmitrij Lichaczow. Dalsza historia nie potoczyła się jednak tak, jak tego chciał. Stąd prawdopodobnie wzięła się jego decyzja o częściowej emigracji za ocean. W ostatnim czasie krytyka systemu władzy, jaki ukształtował się w ostatnich dwóch dekadach, łączy się u niego z troską o przyszłość kraju i jego integralność terytorialną. Pojawiają się odwieczne pytania o historyczne drogi Rosji - czy ma ona kroczyć jakąś własną drogą, czy obrać zachodnią trajektorię historyczną. Chodzi o to, czy Rosja może przełamać „dualny model” swojego rozwoju, polegający z grubsza na tym, że każda zmiana ustrojowa jest w istocie powrotem do tego, co już kiedyś było. Model ten został opisany na materiale historycznym przez Łotmana i Borisa Uspienskiego. Alternatywą dla niego jest „model ternarny”, charakterystyczny dla świata zachodniego, w którym wszelka rewolucja nie prowadzi do całkowitego zniszczenia istniejącego stanu i rzeczy i restauracją starego porządku, lecz jest krokiem naprzód, dzięki sięgnięciu do zasobów ideowych neutralnej „trzeciej” strefy. Gorbaczowowska pieriestrojka rozbudziła nadzieje na zerwanie z tym fatalistycznym powtarzaniem tego samego archaicznego modelu zmiany. Nadzieje te jednak nie ziściły się i Rosja z początkiem nowego stulecia weszła w stare, dobrze sobie znane, koleiny.

\section{$*$}

I na zakończenie jeszcze kilka słów o samym projekcie Symbolarium. Jak już wspomniano, tematem „symbol w kulturze" semiotycy z grupy Tartu-Moskwa zajęli się systematycznie dość późno, bo dopiero w drugiej połowie lat 8o. Ważnym wydarzeniem stała się w tym zakresie publikacja tomu Symbol w systemie kultury w 1987 roku w tartuskiej serii semiotycznej z artykułami Władimira Toporowa, Jurija Łotmana, Dmitrija Lichaczowa, Michaiła Gasparowa i innych autorów. 
Wiaczesław Iwanow miał już dobrze przetarty szlak, kiedy po kilkudziesięcioletniej przerwie powrócił do tej samej problematyki w nowej sytuacji geopolitycznej i w oparciu o nowe, wyżej wymienione moskiewskie placówki naukowe, którymi sam kierował i które powołał do życia. Badania zaczęły przybierać formy organizacyjne: w 2011 roku zorganizowano letnią szkołę Symbolarium, Instytut Kultury Światowej zaczął wydawać periodyk "Antropologia kultury", w którym często pojawiały się artykuły poświęcone fundamentalnej triadzie „Archetyp - Symbol - Znak”. Na drugiej uczelni, Rosyjskim Państwowym Uniwersytecie Humanistycznym (RGGU), ukazywało się z kolei, redagowane przez Iwanowa, czasopismo „Prace rosyjskiej szkoły antropologicznej", którego dwa zeszyty (nr 10 z 2010 roku i nr 13 z 2013) w całości są poświecone „symbolom w historii i w kulturze”, a więc uwzględniają także diachroniczny aspekt projektu Symbolarium.

Po tych zachęcających początkach przyszłość, niestety, nie rysuje się zbyt optymistycznie. Po odejściu założyciela wspomnianych instytucji i spiritus movens całego projektu oraz zmianach klimatu politycznego w kraju może on podzielić los wielu wcześniejszych rosyjskich inicjatyw naukowych, które zakończyły swój żywot, nim zdążyły rozwinąć się w pełni.

\section{Abstract}

\section{Bogusław Żyłko}

UNIVERSITY OF GDAŃSK, THE UNIVERSITY OF HUMANITIES AND ECONOMICS IN LODZ

Vyacheslav Vsevolodovich Ivanov (1929-2017)

Żyłko outlines VyacheslavVsevolodovich Ivanov's life and the most important biographical events that informing his profile as a researcher, especially his great desire to synthesise knowledge and to bring the humanities and the natural sciences into dialogue. This shows clearly in Ivanov's last research project - "Symbolarium".

\section{Keywords}

Russian humanities in the twentieth century, Moscow (Peredelkino), Indo-European studies, cultural semiotics 